\title{
Warfarinbehandling ved atrieflimmer i allmennpraksis - undervurderes blødningsrisikoen?
}

\begin{abstract}
BAKGRUNN Atrieflimmer femdobler risikoen for tromboembolisk hjerneslag. Warfarinbehandling reduserer risikoen med $64 \%$, men øker risikoen for alvorlig blødning. Vi ville undersøke kvaliteten på warfarinbehandlingen i en allmennpraksis og beregne hvilke pasienter som hadde sannsynlig gevinst av behandlingen.
\end{abstract}

MATERIALE OG METODE Vi gjorde en retrospektiv registrering av pasienter med atrieflimmer og beregnet tromboembolisk risiko ( $\mathrm{CHA}_{2} \mathrm{DS}_{2}$-VASc-skår) og blødningsrisiko (HAS-BLED-skår) for hver pasient. Absolutt blødningsrisiko ble beregnet med to alternativer basert på studiene Euro Heart Survey on Atrial Fibrillation (EHS) og SPORTIF. Forventet nettogevinst av warfarinbehandling ble beregnet slik: Redusert tromboembolisk risiko (risiko for tromboemboli $\times 0,64$ ) $\div$ Risiko for alvorlig blødning.

RESULTATER 112 pasienter hadde atrieflimmer. Median alder var 79 år, $60 \%$ var menn. Av pasientene med $\mathrm{CHA}_{2} \mathrm{DS}_{2}$-VASc-skår $\geq 2$ brukte $85 \%$ warfarin eller nye orale antikoagulasjonsmidler, mens den tilsvarende andelen ved lavere risikoskår var $13 \% .69 \%$ av INRmålingene var i målområdet. Av 79 pasienter med $\mathrm{CHA}_{2} \mathrm{DS}_{2}$-VASc-skår $\geq 3$ hadde samtlige forventet gevinst av behandlingen når den var basert på EHS-studien og 72 når den var basert på SPORTIF, men ved lavere risiko ga de to beregningsalternativene ulikt resultat. Beregnet ut fra SPORTIF-studien hadde to av 33 pasienter med $\mathrm{CHA}_{2} \mathrm{DS}_{2}$-VASc-skår $<3$ forventet gevinst av behandlingen.

FORTOLKNING Ved høy tromboembolisk risiko beregnet vi en overbevisende gevinst av warfarinbehandling. Ved lavere risiko var nettogevinsten hos våre pasienter avhengig av hvilken studiepopulasjon som lå til grunn for beregningen. EHS-populasjonen danner grunnlaget for europeiske retningslinjer for antikoagulasjonsbehandling, men synes å avvike fra pasientene i norsk allmennpraksis. Det kan føre til undervurdering av blødningsrisikoen.

Atrieflimmer forekommer hos ca. $10 \%$ av befolkningen over 75 år, og hyppigheten øker med alder. Tilstanden gir en femdobling av risikoen for tromboembolisk hjerneslag (1). Paroksysmal atrieflimmer synes å gi samme risiko som permanent atrieflimmer $(2,3)$.

Det er stor individuell variasjon i tromboembolisk risiko og det anbefales å gjøre en risikovurdering for hver enkelt pasient ved bruk av $\mathrm{CHA}_{2} \mathrm{DS}_{2}$-VASc-skår $(4,5)$ (tab 1). I 2011 publiserte Olesen og medarbeidere en studie som brukte $\mathrm{CHA}_{2} \mathrm{DS}_{2}$-VASc-skår på det danske helseregisteret (6). Denne studien viser at den årlige tromboemboliske risikoen hos pasienter med ubehandlet atrieflimmer varierte fra $0,8 \%$ til $23,6 \%$, avhengig av risikoskår ( $\operatorname{tab} 2$ ).

Antikoagulasjonsbehandling med warfarin ble $\mathrm{i}$ en metaanalyse beregnet å gi en relativ risikoreduksjon på $64 \%$ (95\% KI 49-74\%) for å få slag (7). Nye orale antikoagulasjonsmidler (NOAC), direkte trombinhemmere og faktor 10a-hemmere er sammenliknet med warfarin i en rekke store studier $(8-10)$ og er blitt aktuelle alternativer. De siste retningslinjene fra European Society of Cardiology
(ESC) (3) anbefaler de nye preparatene som førstevalg, gir liten plass for acetylsalisylsyre og anbefaler antikoagulasjon ved lavere tromboembolisk risiko enn før $\left(\mathrm{CHA}_{2} \mathrm{DS}_{2}\right.$-VAScskår $\geq 1)$.

Antikoagulasjonsbehandling gir økt blødningsrisiko. Alvorlige blødninger blir definert som hemoglobinfall $>2 \mathrm{~g} / \mathrm{dl}$, behov for transfusjon eller intrakranial blødning. Det svenske registeret for antikoagulasjonsbehandling, AURICULA, fant at årlig risiko for alvorlig blødning var $2,6 \%(11)$, i en norsk allmennpraksis var den $2,4 \%$ (12). Disse tallene gjelder warfarinbehandling på alle indikasjoner (atrieflimmer, lungeemboli, venetrombose og klaffeoperasjon). I de nye atrieflimmerstudiene (8-10) er risikoen for alvorlig blødning ved warfarinbehandling høyere $(3,1-3,4 \%)$.

Det er også utviklet en metode for å beninger, HAS-BLED-skår (tab 3), som er anbefalt av European Society of Cardiology (3) og av norske spesialister (4). Metoden er validert $i$ to studier, en med lav og en med høy blødningsrisiko $(13,14)$ (tab 4). Dette gir mulighet for å sammenholde fordelen regne individuell risiko for alvorlige blød-

\author{
Bjørn Bratland \\ bjorn@bratland.no \\ Magn-Bjørn Hornnes \\ Legegruppen Grandgården \\ Arendal \\ Il \\ Engelsk oversettelse på www.tidsskriftet.no \\ > Se lederartikkel side 131

\section{HOVEDBUDSKAP} \\ I en allmennpraksis hadde $85 \%$ av pasiente- \\ ne med atrieflimmer og tromboembolisk \\ risiko tilsvarende $\mathrm{CHA}_{2} \mathrm{DS}_{2}$-VASc-skår $\geq 2$ \\ effektiv antikoagulasjon
}

Ved høy tromboembolisk risiko var det stor beregnet gevinst ved warfarinbehandling

Ved lav/moderat tromboembolisk risiko var beregnet gevinst avhengig av beregningsmetode

Ved bruk av europeiske retningslinjer for antikoagulasjonsbehandling på vår pasientgruppe ser det ut til at blødningsfaren undervurderes 
Tabell $1 \mathrm{CHA}_{2} \mathrm{DS}_{2}$-VASc-skår (Congestive heart failure, Hypertension, Age > 75, Diabetes, prior Stroke/TIA, Vascular disease, Age 65-74, Sex categoryl for beregning av risiko for tromboembolisk hjerneslag hos pasienter med atrieflimmer. De ulike tilstandene som inngår i skåringen teller med 1 eller 2 poeng og gir totalskàr 0 -9 (5)

\begin{tabular}{lc} 
Risikofaktor & Poeng \\
Hjertesvikt & 1 \\
Hypertensjon & 1 \\
Alder > 75 år & 2 \\
Diabetes & 1 \\
Tidligere hjerneslag & 2 \\
Annen vaskulær sykdom & 1 \\
Alder 65-74 & 1 \\
Kvinne & 1 \\
\hline
\end{tabular}

ved antikoagulasjon mot ulempen ved økt blødningsrisiko for den enkelte pasient.

Warfarinbehandling i Norge har i stor grad vært gjennomført av allmennleger som har opparbeidet betydelig erfaring (12) med god kvalitetssikring (15). Formålet med denne undersøkelsen er å studere warfarinbehandling av pasienter med atrieflimmer $i$ en allmennpraksis ved å se på måloppnåelse for INR-verdiene, kartlegge behandlingen ved forskjellige nivåer for tromboembolisk risiko og beregne gevinsten ved warfarinbehandling ved også å beregne blødningsrisiko.

\section{Materiale og metode}

Legegruppen Grandgården i Arendal har seks fastleger. Vi søkte i datajournalene på diagnosen «atrieflimmer» for årene $2010 \mathrm{og}$ 2011, og inkluderte i studien alle listepasienter som hadde diagnosen atrieflimmer november 2011 (fig 1). Vi inkluderte pasienter med paroksysmal atrieflimmer selv om de hadde sinusrytme på dette tidspunktet. Pasienter som var vellykket operert med ablasjonsbehandling, ble ikke tatt med. Vi leste gjennom journalene og registrerte følgende variabler: Alder, kjønn, type og varighet av atrieflimmer, eventuell ablasjonsbehandling, antikoagulasjonsbehandling, dens varighet og eventuell årsak til seponering, alle INR-målinger i ett år (november 2010-november 2011) og alle data som var nødvendig for å beregne $\mathrm{CHA}_{2} \mathrm{DS}_{2}$-VAScskår og HAS-BLED-skår (tab 1, tab 3).

De fleste opplysningene ble funnet $i$ journalenes resymédel, laboratoriedel og i faste medikamenter, men vi søkte også i hele journalteksten og i noen epikriser. Diagnosen hypertensjon ble registrert når pasienten brukte antihypertensiver utover betablokkere, som de fleste hadde som frekvensregulering, men ikke hvis medikamentene var en del av hjertesviktbehandling. Dårlig blodtrykkskontroll ble notert hvis minst én av de tre siste målingene hadde systolisk blodtrykk $\geq 160 \mathrm{~mm} \mathrm{Hg}$. Diabetes ble registrert uansett behandling.

$\mathrm{Vi}$ beregnet $\mathrm{CHA}_{2} \mathrm{DS}_{2}$-VASc-skår og absolutt risiko for tromboemboli for hver enkelt pasient etter de nyeste data fra Olesen og medarbeideres studie (6). Ved beregning av blødningsrisiko med HAS-BLED-meto-

Tabell 2 Årlig absolutt risiko for tromboembolisk hjerneslag hos pasienter med ubehandlet atrieflimmer ved forskjellig $\mathrm{CHA}_{2} \mathrm{DS}_{2}-\mathrm{VASc}$-skår basert på tall fra det danske helseregisteret (6) og beregnet årlig absolutt risiko og absolutt risikoreduksjon med warfarinbehandling ut fra en relativ risikoreduksjon på $64 \%$ (7)

\begin{tabular}{lccc} 
Arrlig absolutt & $\begin{array}{c}\text { Årlig absolutt risiko } \\
\text { risiko ubehandlet } \\
(\%)\end{array}$ & $\begin{array}{c}\text { Absolutt risikoreduksjon } \\
\text { med } \begin{array}{c}\text { (\%) } \\
\text { med warfarinbehandling } \\
(\%)\end{array}\end{array}$ \\
0 & 0,8 & 0,3 & 0,5 \\
1 & 2,0 & 0,7 & 1,3 \\
2 & 3,7 & 1,3 & 2,4 \\
3 & 5,9 & 2,1 & 3,8 \\
4 & 9,3 & 3,4 & 5,9 \\
5 & 15,3 & 5,5 & 9,8 \\
6 & 19,7 & 7,1 & 12,6 \\
7 & 21,5 & 7,7 & 13,8 \\
8 & 22,4 & 8,1 & 14,3 \\
9 & 23,6 & 8,5 & 15,1 \\
\hline
\end{tabular}

den brukte vi to alternativer. Alternativ 1 bygger på Euro Heart Survey-studien (13), der man fant en årlig forekomst av alvorlig blødning hos $1,5 \%$ av deltakerne. Alternativ 2 bygger på SPORTIF-studiene (14), der årlig forekomst av alvorlig blødning var $3,7 \%$. Med en forventet $64 \%$ relativ risikoreduksjon ved warfarinbehandling (7) kunne vi regne ut gevinsten ved behandling slik: Nettogevinsten ved warfarinbehandling $=$ Redusert tromboembolisk risiko (risiko for tromboemboli $\times 0,64) \div$ Risiko for alvorlig blødning. For eksempel vil en mannlig atrieflimmerpasient på 70 år med hypertensjon ha en $\mathrm{CHA}_{2} \mathrm{DS}_{2}$-VASc-skår på 2 (tab 1$)$ og en årlig risiko for tromboemboli på 3,7\% (tab 2). Hvis han har en HAS-BLED-skår på 1 ( $\operatorname{tab} 3$ ), har han en årlig risiko for alvorlig blødning på 1,0\% (alternativ 1) eller 3,4\% (alternativ 2). Beregnet nettogevinst av warfarinbehandling ved alternativ 1 vil da være $(3,7 \times 0,64) \div 1,0=1,4$, altså positiv nettogevinst. Ved alternativ 2 blir beregningen $(3,7 \times 0,64) \div 3,4=\div 1,0$, altså negativ nettogevinst.

Alle data ble lagt inn i statistikkprogrammet NSD-stat. Ved beregning av sentralverdier i datasettene ble medianverdien brukt.

Studien er lagt frem for Regional etisk komité, som anbefaler den gjennomført, men vurderer den som et kvalitetssikringsprosjekt. Studien er godkjent av Norsk samfunnsvitenskapelig datatjeneste.

\section{Resultater}

Det ble funnet 139 pasienter registrert med diagnosen atrieflimmer i perioden 2010-2011. 112 med verifisert atrieflimmer i november 2011 ble inkludert i studien (fig 1). 1.12. 2011 hadde vi 5962 listepasienter som ga en prevalens for atrieflimmer på 1,9\%. Median alder var 79,0 år med spredning 17-94 år, 60\% var menn. 76 pasienter hadde permanent atrieflimmer, 25 hadde paroksysmal atrieflimmer og 11 hadde persisterende atrieflimmer.

\section{Antikoagulasjonsbehandling}

82 pasienter $(73 \%)$ brukte warfarin, fire av disse i kombinasjon med platehemmer. 16 pasienter $(14 \%)$ brukte kun acetylsalisylsyre eller annen platehemmer, to brukte nye orale antikoagulasjonsmidler og 12 pasienter $(10 \%)$ brukte ingen antikoagulasjon. 81 av warfarinbrukerne gjennomførte kontrollene på legekontoret med til sammen 751 INR-målinger i løpet av ett år, medianverdi 9,3 (spredning 5-16) målinger per pasient per år. Det gir et intervall på 5,6 uker mellom hver prøve. Av INR-målingene var $69 \%$ innenfor målområdet, $14 \%$ under og $17 \%$ over. Målområdet var INR 2,0-3,0, bortsett fra fem klaffeopererte med INR-målområde 2,5-3,5. Behandlingstiden for pågående antikoagulasjon var 0-24 år, medianverdi 
5,0 år. Varighet av atrieflimmer var 0-25 år, medianverdi 5,7 år.

30 pasienter $(27 \%)$ brukte ikke warfarin, hvorav $11(10 \%)$ aldri hadde brukt det. 19 pasienter $(17 \%)$ hadde brukt warfarin tidligere, hvorav sju hadde seponert på grunn av høy blødningsrisiko og 12 på grunn av lav tromboembolisk risiko.

Tromboembolisk risiko og blødningsrisko Pasientgruppens medianverdi for $\mathrm{CHA}_{2} \mathrm{DS}_{2}-$ VASc-skår var 4,0 (spredning 0-8). Pasientene ble fordelt $\mathrm{i}$ risikogrupper etter $\mathrm{CHA}_{2} \mathrm{DS}_{2}$-VASc-skår, med oversikt over antikoagulasjon i hver gruppe (fig 2). 15 pasienter skåret $\leq 1$. Av disse brukte to $(13 \%)$ warfarin, seks (40\%) acetylsalisylsyre og sju (47\%) var uten behandling. Av 97 pasienter med $\mathrm{CHA}_{2} \mathrm{DS}_{2}$-VASc-skår $\geq 2$ brukte 82 $(85 \%)$ warfarin eller nye orale antikoagulasjonsmidler, ti (10\%) platehemmere og fem $(5 \%)$ var uten behandling. 88 pasienter (79\%) hadde HAS-BLED-skår 0-2, mens 24 $(21 \%)$ hadde HAS-BLED-skår $\geq 3$.

\section{Gevinst ved behandling}

Gevinst ved behandling ble regnet ut etter begge HAS-BLED-studiene, både populasjonen fra EHS (alternativ 1) og fra SPORTIF (alternativ 2). Ved alternativ 1 ville 102 pasienter $(91 \%)$ ha beregnet gevinst av antikoagulasjonsbehandling. Ved alternativ 2 ville $74(66 \%)$ ha gevinst. Vi fant ingen gevinst av å behandle pasienter med $\mathrm{CHA}_{2} \mathrm{DS}_{2}$-VASc-skår $=0$ (tab 5). Ved skår 1 og 2 var det store forskjeller mellom de to beregningsmåtene. Ved bruk av EHS-populasjonen var det gevinst hos henholdsvis $75 \%$ og $94 \%$ av våre pasienter, men ved bruk av SPORTIF-populasjonen var andelen pasienter med gevinst henholdsvis $12 \%$ og $6 \%$. Ved $\mathrm{CHA}_{2} \mathrm{DS}_{2}-$ VASc-skår $=3$ var det bedre samsvar mellom beregningsmetodene, og ved skår $\geq 4$ viste begge beregningsmetodene at alle våre pasienter ville ha betydelig gevinst av warfarinbehandling.

\section{Diskusjon}

$85 \%$ av våre pasienter med $\mathrm{CHA}_{2} \mathrm{DS}_{2}$ VASc-skår $\geq 2 \operatorname{og} 75 \%$ av samtlige av våre pasienter med atrieflimmer brukte warfarin eller nye orale antikoagulasjonsmidler. $69 \%$ av INR-målingene lå innenfor terapeutisk område.

Pasientene med høy tromboembolisk risiko hadde stor beregnet gevinst av warfarinbehandling, også ved høy blødningsrisiko. Hos pasientene med lav tromboembolisk risiko var den beregnede absolutte risikoreduksjonen så liten at blødningsrisikoen oppveide fordelene.

Andelen warfarinbrukere blant pasienter med atrieflimmer i medlemslandene til European Society of Cardiology i 2003 var
Tabell 3 HAS-BLED-skår (Hypertension, Abnormal Renal/Liver Function, Stroke, Bleeding History or Predisposition, Labile INR, Elderly, Drugs/Alcohol Concomitantlyl for beregning av risiko for alvorlig blødning under warfarinbehandling ved atrieflimmer. De ulike tilstandene som inngår i skåringen teller med 1 poeng og gir totalskår 0-9 (13)

$\begin{array}{lc}\text { Risikofaktor } & \text { Poeng } \\ \text { Systolisk blodtrykk >160 mm Hg } & 1 \\ \text { Nyresvikt (kreatinin > } 200 \mu \mathrm{mol} / \mathrm{l}) & 1 \\ \text { Leversykdom (ALAT > } 3 \times \text { grenseverdi) } & 1 \\ \text { Tidligere hjerneslag } & 1 \\ \text { Tidligere alvorlig blødning } & 1 \\ \text { Labil INR (< } 60 \% \text { av verdiene i terapeutisk område) } & 1 \\ \text { Alder > } 65 \text { år } & 1 \\ \text { Bruk av ikke-steroide antiinflammatoriske midler eller blodplatehemmere } & 1 \\ \text { Stort alkoholforbruk } & 1\end{array}$

Tabell 4 Årlig absolutt risiko for alvorlig blødning under warfarinbehandling hos pasienter med atrieflimmer ved forskjellig HAS-BLED-skår beregnet i studiene Euro Heart Survey (13) og SPORTIF (14)

\begin{tabular}{lcc}
\hline & \multicolumn{2}{c}{ Årlig absolutt risiko for alvorlig blødning (\%) } \\
\cline { 2 - 3 } HAS-BLED-skår & Euro Heart Survey & SPORTIF \\
0 & 1,1 & 0,9 \\
1 & 1,0 & 3,4 \\
2 & 1,9 & 4,1 \\
3 & 3,7 & 5,8 \\
4 & 8,7 & 8,9 \\
51 & 12,5 & 9,1 \\
\hline
\end{tabular}

${ }^{1}$ Ingen av studiene hadde pasienter med høyere HAS-BLED-skår enn 5

Tabell 5 Antall av 112 pasienter med atrieflimmer ved Legegruppen Grandgården i perioden 2010-11 som beregnes å ha nettogevinst av warfarinbehandling basert på to ulike studier

\begin{tabular}{|c|c|c|c|c|c|c|}
\hline \multirow{3}{*}{$\begin{array}{l}\mathrm{CHA}_{2} \mathrm{DS}_{2-} \\
\text { VASc-skår }\end{array}$} & \multirow{3}{*}{$\begin{array}{c}\text { Antall } \\
\text { pasienter } \\
(\mathrm{n}=112)\end{array}$} & \multicolumn{5}{|c|}{ Pasienter med beregnet nettogevinst av warfarinbehandling ${ }^{1}$} \\
\hline & & \multicolumn{2}{|c|}{ Basert på EHS-studien } & \multicolumn{3}{|c|}{ Basert på SPORTIF-studien } \\
\hline & & Antall & Prosent $(95 \% \mathrm{KI})$ & Antall & Proser & $(95 \% \mathrm{KI})$ \\
\hline 0 & 7 & 0 & $(0-41)$ & 0 & 0 & $(0-41)$ \\
\hline 1 & 8 & 6 & $75 \quad(35-97)$ & 1 & 12 & $(3-53)$ \\
\hline 2 & 18 & 17 & $94 \quad(72-100)$ & 1 & 6 & $(0-27)$ \\
\hline 3 & 12 & 12 & $100 \quad(74-100)$ & 5 & 42 & $(15-72)$ \\
\hline $4-8$ & 67 & 67 & $100 \quad(95-100)$ & 67 & 100 & $(95-100)$ \\
\hline
\end{tabular}

1 Tromboembolisk absolutt risikoreduksjon er større enn absolutt risiko for alvorlig blødning. Risiko for tromboembolisk hjerneslag er beregnet fra det danske helseregisteret (6). Relativ risikoreduksjon ved warfarinbehandling er satt til $64 \%$ (7). Risiko for alvorlig blødning er beregnet med HAS-BLED-skår med to alternative behandling er satt til $64 \%$ (7). Risiko for alvorlig blødning
studier, Euro Heart Survey (EHS) (13) og SPORTIF (14) 


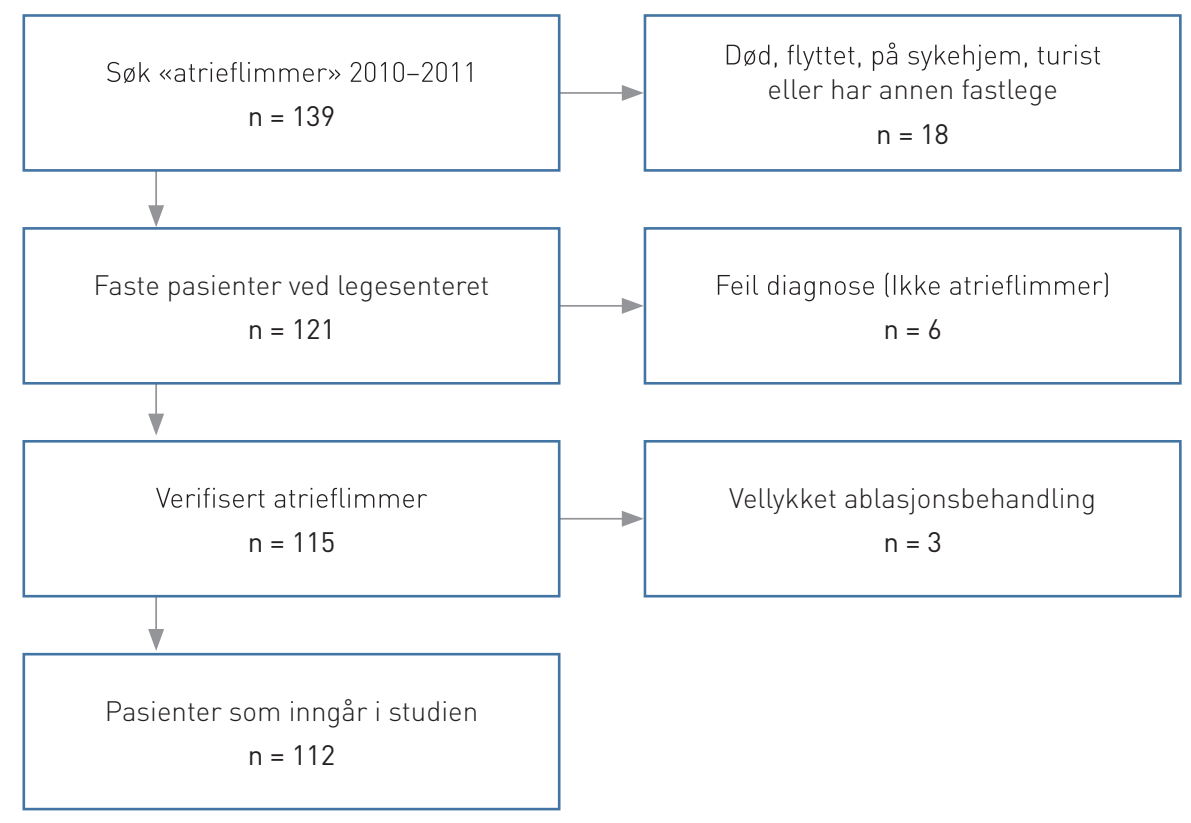

Figur 1 Flytskjema for inklusjon av pasienter med atrieflimmer ved Legegruppen Grandgården 2010-11

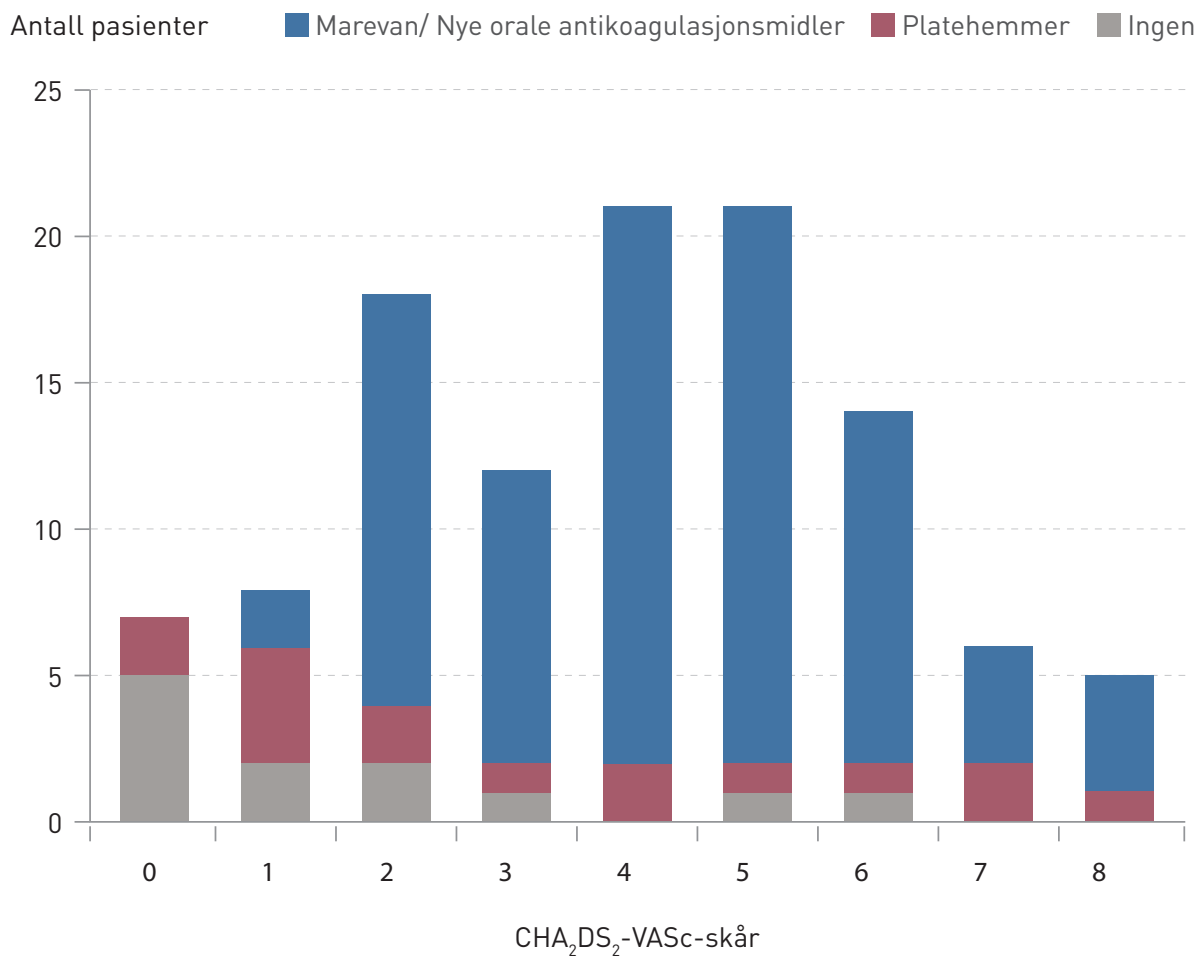

Figur 2 Antikoagulasjonsbehandling hos 112 pasienter med atrieflimmer ved forskjellig $\mathrm{CHA}_{2} \mathrm{DS}_{2}$-VASC-skår hos Legegruppen Grandgården 2010-11

$65 \%$ (16), og det samme var tilfelle i 2013 (17). INR-verdier i målområdet ved vårt legekontor i 2006 var $57 \%$ (12). I de tre store atrieflimmerstudiene som dannet grunnlaget for introduksjon av nye orale antikoagulasjonsmidler, var $64 \%(8), 55 \%$ (9) og $66 \%$ (10) av målingene i terapeutisk område, og i det svenske registeret var denne andelen $76 \%$
(11). Forklaringen på den høye andelen av warfarinbrukere og bedring av INR-verdiene i en norsk allmennpraksis kan være lang erfaring med warfarinbehandling (12) og god norsk kvalitetssikring (15).

Beregnet gevinst av behandlingen var svært avhengig av beregningsmetode. Ved bruk av populasjonen i EHS-studien med lav blødningsrisiko hadde nesten alle pasienter med $\mathrm{CHA}_{2} \mathrm{DS}_{2}$-VASc-skår $>0$ gevinst av warfarinbehandling, slik European Society of Cardiology anfører (3). Ved bruk av populasjonen i SPORTIF-studien med høy blødningsrisiko var det liten gevinst ved $\mathrm{CHA}_{2} \mathrm{DS}_{2}$-VASc-skår $<3$. Her er altså valg av populasjoner viktig premiss for resultatet.

Euro Heart Survey on Atrial Fibrillation beskrev «real-life»-behandling av atrieflimmer hos 5333 pasienter fra forskjellige typer kardiologipraksiser i 35 medlemsland av European Society of Cardiology (16). Studien ble utgangspunkt for å konstruere risikoskårene $\mathrm{CHA}_{2} \mathrm{DS}_{2}$-VASc-skår (5) og HASBLED-skår (13). EHS-studien hadde kun ett års observasjonstid, pasientene hadde lav gjennomsnittsalder (66 år) og kun $65 \%$ brukte warfarin. Ved utviklingen av HAS-BLEDskår anvendte man hele pasientmaterialet $\mathrm{i}$ studien (også de 35\% som ikke fikk antikoagulasjonsbehandling). Hyppigheten av alvorlige blødninger var derfor kun $1,5 \%$. De absolutte risikoverdiene for alvorlig blødning viser av den grunn lave verdier (tab 4). Først ved HAS-BLED-skår $=3$ passerer absolutt risiko for alvorlig blødning 3\%. European Society of Cardiologys retningslinjer tar utgangspunkt i denne studien når de anbefaler bruk av HASBLED-metoden og anfører at HAS-BLEDskår $=3$ er faregrensen for blødning $(3,4)$. Forfatterne av denne første HAS-BLEDundersøkelsen mente det kunne foreligge en undervurdering av blødningsrisiko og at flere studier trengtes (13). Dette ble gjort da HASBLED-skår ble anvendt på studiene

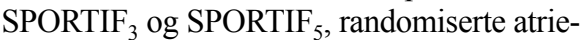
flimmerstudier der alle deltakerne fikk antikoagulasjonsbehandling (14). Gjennomsnittlig risiko for alvorlige blødninger her var $3 \%$, omtrent som i de andre nyere atrieflimmerstudiene (8-10), og allerede ved HAS-BLEDskår $=1$ passeres $3 \%$ absolutt risiko for alvorlig blødning (tab 4).

I vår egen studie fra 2006 (12) av warfarinbehandling $\mathrm{i}$ allmennpraksis var årlig risiko for alvorlig blødning 2,4\%, men undergruppen med atrieflimmer hadde $3,7 \%$ risiko. Vi tror at beregningene utført på SPORTIF-studiene med ca. 3\% årlig risiko for alvorlig blødning ligger nærmere den reelle risiko for våre atrieflimmerpasienter enn EHS-studien gjør.

$\mathrm{Vi}$ har forutsatt at warfarin gir $64 \%$ reduksjon av tromboembolisk risiko, basert på en metastudie (7) som bygger på studier gjennomført for mange år siden. Det kan bety en overvurdering av effekten, siden man nå har bedre behandling av hypertensjon og andre risikofaktorer (18).

Vår metode med retrospektiv gjennomgang av pasientjournaler har svakheter. Påliteligheten er størst når man skal registrere «harde» data som kjønn, alder, diagno- 
ser, medikamenter og laboratoriesvar, mens sykehistoriene kan være ufullstendige. Det kan foreligge underrapportering av data, særlig med tanke på blødningsrisiko (alkoholbruk, håndkjøp av ikke-steroide antiinflammatoriske midler m.m.). På den annen side er det en styrke at dette er en rapport fra vanlig norsk allmennpraksis.

Vårt «regnskap» ved beregning av netto gevinst ved antikoagulasjon forutsatte at vi vurderte en alvorlig blødning like alvorlig som et tromboembolisk slag. Dette kan diskuteres. Utfallet av begge tilstander kan variere fra død til moderat sykdom uten sekveler. Regnestykket er likevel en påminnelse om at vi ikke må påføre pasienten mer skade enn nytte med vår behandling.

I 2011 brukte kun to av våre pasienter et nytt oralt antikoagulasjonsmiddel (dabigatran), men bruken av disse vil øke betydelig (19). Preparatene krever ingen INR-kontroll, men likevel nøye overvåking av blødningsfaren (20). Kunnskapssenteret har anført at kunnskapsgrunnlaget for de nye antikoagulasjonsmidlene er noe svakt og at deres plass $i$ behandlingen fortsatt er uavklart (21).

Vi finner lite gevinst av warfarinbehandling ved lav tromboembolisk risiko. I en studie av den amerikanske ATRIA-populasjonen der over 13000 pasienter med atrieflimmer følges gjennom sju år, gjøres en liknende gevinstvurdering (18). Studien er retrospektiv, beregningsmetoden er annerledes og man bruker hjerneblødning i stedet for HAS-BLED-skår, men det konkluderes på samme måte med at det er liten gevinst av warfarinbehandling ved lav tromboembolisk risiko. I European Society of Cardiologys retningslinjer anbefales det å antikoagulasjonsbehandle pasienter med $\mathrm{CHA}_{2} \mathrm{DS}_{2}$ VASc-skår $\geq 1$ (med unntak av kvinner $<65$ år uten andre risikofaktorer). Kan denne anbefalingen bygge på et for lavt estimat av blødningsrisiko? Ved bruk av SPORTIF-studien går ikke vårt «regnskap» i pluss før $\mathrm{CHA}_{2} \mathrm{DS}_{2}$-VASc-skår $=3$. Vårt materiale er lite og metoden har svakheter, men resultatene tilsier at det bør gjennomføres prospektive, kontrollerte studier for å avgjøre om antikoagulasjonsbehandling ved atrieflimmer gir samlet gevinst hos pasienter med lav tromboembolisk risiko.

Vi takker Christian Borchgrevink, Harald Reiso og de øvrige medlemmene $i$ forskergruppen med allmennpraktikere fra Agder for inspirerende assistanse.

Denne studien er finansiert gjennom stipend fra Allmennmedisinsk forskningsutvalg.

\section{Bjørn Bratland (f. 1946)}

er spesialist i allmennmedisin og fastlege. Forfatter har fylt ut ICMJE-skjemaet og oppgir ingen interessekonflikter.

\section{Magn-Bjørn Hornnes (f. 1948)}

er spesialist i allmennmedisin og fastlege. Forfatter har fylt ut ICMJE-skjemaet og oppgir ingen interessekonflikter.

\section{Litteratur}

1. Wolf PA, Abbott RD, Kannel WB. Atrial fibrillation as an independent risk factor for stroke: the Framingham Study. Stroke 1991: 22: 983-8.

2. Risøe C, Gjesdal K. Antikoagulasjonsbehandling ved forbigående atrieflimmer. Tidsskr Nor Lægeforen 2004: 124: $950-2$

3. Camm AJ, Lip GY, Caterina R et al. 2012 focused update of the ESC Guidelines for the mangagement of atrial fibrillation. Eur Heart J 2012; 33: 2719-47.

4. Aamodt AH, Sandset PM, Atar D et al. Atrieflimmer og hjerneslag. Tidsskr Nor Legeforen 2013; 133: $1453-7$

5. Lip GY, Nieuwlaat R, Pisters R et al. Refining clinical risk stratification for predicting stroke and thromboembolism in atrial fibrillation using a novel risk factor-based approach: the euro heart survey on atrial fibrillation. Chest 2010; 137: 263-72.

6. Olesen JB, Lip GY, Hansen ML et al. Validation of risk stratification schemes for predicting stroke and thromboembolism in patients with atrial fribrillation: nationwide cohort study. BMJ 2011 342: $1-9$.

7. Hart RG, Pearce LA, Aguilar MI. Meta-analysis: antithrombotic therapy to prevent stroke in patients who have nonvalvular atrial fibrillation. Ann Intern Med 2007; 146: 857-67.

8. Connolly SJ, Ezekowitz MD, Yusuf S et al. Dabigatran versus warfarin in patients with atrial fibrillation. N Engl J Med 2009: 361: 1139-51.
9. Patel MR, Mahaffey KW, Garg J et al. Rivaroxaban versus warfarin in nonvalvular atrial fibrillation. N Engl J Med 2011; 365: 883-91.

10. Granger CB, Alexander JH, McMurray JJV et al. Apixaban versus warfarin in patients with atria fibrillation. N Engl J Med 2011; 365: 981-92.

11. Wieloch M, Själander A, Frykman V et al. Anticoagulation control in Sweden: reports of time in therapeutic range, major bleeding, and thromboembolic complications from the national quality registry AuriculA. Eur Heart J 2011: 32: 2282-9.

12. Bratland B. Warfarinbehandling i allmennpraksis. Tidsskr Nor Lægeforen 2006; 126: 162-5.

13. Pisters R, Lane DA, Nieuwlaat $R$ et al. A novel user-friendly score (HAS-BLED) to assess 1-year risk of major bleeding in patients with atrial fibrillation: the Euro Heart Survey. Chest 2010; 138: 1093-100.

14. Lip GY, Frison L, Halperin JL et al. Comparative validation of a novel risk score for predicting bleeding risk in anticoagulated patients with atrial fibrillation: the HAS-BLED (Hypertension, Abnormal Renal/Liver Function, Stroke, Bleeding History or Predisposition, Labile INR, Elderly, Drugs/ Alcohol Concomitantly) score. J Am Coll Cardiol 2011: 57: 173-80.

15. Reikvam $\AA$, Sandset PM, red. Warfarinbehandling i praksis - tryggere antikoagulasjon. 2. utg. Skrift serie for leger: Utdanning og kvalitetsutvikling. Oslo: Den norske legeforening, 2010. http://legeforeningen.no/PageFiles/25973/ Warfarinbehandling $\% 20 i \% 20$ praksis.pdf (6.12.2013)

16. Nieuwlaat R, Capucci A, Camm AJ et al. Atrial fibrillation management: a prospective survey in ESC member countries: the Euro Heart Survey on Atrial Fibrillation. Eur Heart J 2005; 26: 2422-34.

17. Ingen bedring i slagforebygging. Pressemelding fra ESC 2013. Dagens Medisin 4.9.2013.

18. Singer DE, Chang $Y$, Fang $M C$ et al. The net clinical benefit of warfarin anticoagulation in atrial fibrillation. Ann Intern Med 2009; 151: 297-305.

19. Nasjonal rådgivende spesialistgruppe innen antikoagulasjon. Informasjon om de nye perorale antikoagulasjonsmidlene dabigatran, rivaroksaban og apiksaban. Oslo: Helsedirektoratet, Statens legemiddelverk, 2013

20. Ghanima W, Atar D, Sandset PM. Nye perorale antikoagulasjonsmidler - en oversikt. Tidsskr Nor Legeforen 2013; 133: 1940-5.

21. Efficacy and cost-effectiveness of new oral anticoagulants compared to warfarin for the prevention of stroke in patients with atrial fibrillation. Oslo: Nasjonalt kunnskapssenter for helsetjenesten, 2013. www.kunnskapssenteret.no/ publikasjoner/efficacy-and-cost-effectiveness-ofnew-oral-anticoagulants-compared-to-warfarinfor-the-prevention-of-stroke-in-patients-withatrial-fibrillation?language $=$ english (6.12.2013).

Mottatt 3.5. 2013, første revisjon innsendt 26.8. 2013, godkjent 5.12. 2013. Redaktør: Sigurd Høye. 